\title{
Activated charcoal attenuates bitterweed toxicosis in sheep
}

\author{
GEORGE W. POAGE III, CODY B. SCOTT, MATTHEW G. BISSON, AND F. STEVE HARTMANN
}

Authors are former graduate assistant, assistant professor, graduate assistant, Department of Agriculture, Angelo State University, San Angelo, Texas, and University of Texas Lands-Surface Interests, Midland, Texas, respectively.

\section{Abstract}

We assessed the potential of activated charcoal to attenuate bitterweed (Hymenoxys odorata DC.) toxicosis in 3 trials. In Trial 1 , lambs were offered a subacute level $(.264 \% \mathrm{BW})$ of bitterweed and received either $0, .5,1$, or $1.5 \mathrm{~g} / \mathrm{kg} \mathrm{BW}$ of activated charcoal. In Trial 2, lambs were dosed (by gavage) with .264\% BW of bitterweed and varying levels of activated charcoal followed by feeding milo (Sorghum sp.) immediately after dosing. A decrease in milo intake, which indicates aversive postingestive feedback, was interpreted to indicate that toxicosis occurred. In Trial 3, lambs were fed a $20 \%$ CP supplement with or without activated charcoal and then exposed to bitterweed and other forage species growing in pots; we counted the number of bites of each. In Trial 1 , lambs refused to eat bitterweed after 10 days of exposure, thus the study was stopped. In Trial 2, lambs that received 1 or 1.5 $\mathrm{g} / \mathrm{kg} \mathrm{BW}$ of activated charcoal consumed more $(\mathrm{P}<0.05)$ milo than those receiving $0 \mathrm{~g} / \mathrm{kg} \mathrm{BW}$. In Trial 3, lambs supplemented with activated charcoal took more $(P<0.05)$ bites of bitterweed than lambs receiving a protein supplement alone. Lambs readily ate activated charcoal when added to a $20 \%$ crude protein supplement in a $10 \%$ mixture. Collectively, these results suggest activated charcoal will result in continued consumption of bitterweed which suggests avoidance of toxicosis. Activated charcoal also may be effective in preventing bitterweed toxicosis when combined with a supplement.

Key Words: bitterweed, activated charcoal, toxicosis, hymenoxon, Hymenoxys

Bitterweed (Hymenoxys odorata DC.) contains the sesquiterpene lactone hymenoxon, which causes chronic and acute toxicity of sheep in central and western Texas (Ivie et al. 1975, Kim et al. 1975, Pettersen and Kim 1976). Toxicosis typically occurs during winter when nutritious grasses and forbs are dormant (Ueckert and Calhoun 1988). Bitterweed toxicity has reduced economic returns from sheep production in the Edward's Plateau and TransPecos regions of Texas since the early 1900's and has contributed to a $50 \%$ reduction in sheep production in this region over the past 30 years (Ueckert et al. 1980, Conner et al. 1988).

Most ranchers reduce stocking rates or provide supplemental feed when bitterweed toxicity is likely to occur. Some protection

Research was funded by University of Texas Lands-Surface Interests and Angelo State University's Management, Instruction, and Research Center. At the time of the research, Poage and Bisson were Graduate Assistants in the Department of Agriculture.

The authors wish to acknowledge J. Pfister, M. Ralphs, F. Provenza, J. Walker, and 3 anonymous reviewers for reviews of earlier drafts of this manuscript.

Date accepted 23 Feb. 1999.
Resumen

Se condujeron 3 experimentos para evaluar el potencial del carbón activado para atenuar la intoxicación por "Bitterweed" (Hymenoxys odorata D.C.). En el ensayo 1, a los corderos se les ofreció un nivel subagudo [.264\% del peso vivo (PV)] de "Bitterweed' y recibieron alguna de las siguientes dosis de carbón activado $0, .5,1.0, y 1.5 \mathrm{~g} \mathrm{~kg}^{-1} \mathrm{PV}$. En el ensayo 2 a los corderos se les suministró $\mathbf{. 2 6 4 \%}$ de "Bitterweed", niveles variables de carbón activado y se alimentaron con "milo" (Sorghum sp.) inmediatamente después de recibir la dosis de "Bitterweed". Una disminución en el consumo de "milo", lo cual indica un estímulo postingestivo adverso, fue interpretada como un indicador de que la intoxicación ocurrió. El ensayo 3, los corderos se alimentaron con un suplemento con un $20 \%$ de proteína cruda con y sin carbón activado y después fueron expuestos al "Bitterweed" y otras especies forrajeras creciendo en macetas, y contamos el número de mordidas que cada especie recibió. En el ensayo 1 los corderos rechazaron consumir "Bitterweed" después de 10 días de expuestos a ella, y aquí el estudio se detuvo. En el experimento 2, los corderos que recibieron $101.5 \mathrm{~g} \mathrm{~kg}$ 1 PV de carbón activado consumieron mas "milo" $(p<0.05)$ que los que no recibieron carbón activado. En el ensayo 3, los corderos suplementados con carbón activado dieron mas mordidas al "Bitterweed" que los corderos que recibieron el suplemento sin carbón activado. Los corderos consumieron fácilmente el carbón activado cuando se agrego al suplemento proteico en una mezcla del $10 \%$. En conjunto, estos resultados sugieren que el carbón activado resultará en un consumo continuo de "Bitterweed" lo cual sugiere que evita la toxicosis. El carbón activado, cuando se combina con el suplemento, también puede ser efectivo en prevenir la intoxicación por "Bitterweed".

from toxicosis has been observed by adding the antioxidant Santoquin (6-ethoxy-1,2, dihydro- 2,2,4-trimethylquinoline) to mineral supplements (Kim et al. 1982, Calhoun et al. 1988). However, Santoquin reduces palatability when added to supplements at $0.5 \%$ and may be ineffective because of low intake (Calhoun et al. 1986, Ueckert and Calhoun 1988). L-cysteine given intravenously at the proper dosage prevented toxicosis; Lcysteine and hymenoxon must be administered simultaneously and the high cost of cysteine makes this treatment impractical (Rowe et al. 1980, Calhoun et al 1988). Adding a sulfur source to protein supplements also provides some protection from bitterweed toxicosis (Calhoun et al. 1986).

Activated charcoal has been widely documented by human toxicologists to adsorb many classes of poisons (Edwards and McCredie 1967, Decker et al. 1968, Hayden and Comstock 1975, 
Levy 1982), and it has been suggested as an effective treatment for several types of phytotoxicosis (Buck and Bratich 1986). Thus, our objective was to determine if activated charcoal attenuated bitterweed toxicosis. The specific objectives were to determine (1) if activated charcoal increased intake of bitterweed and (2) if sheep consumed a supplement containing activated charcoal.

\section{Methods}

Three trials were conducted at the Angelo State University Management, Instruction, and Research (MIR) Center in San Angelo, Texas, USA. Thirty freshlyweaned crossbred lambs were used in Trials 1 and 2, and 16 lambs were used in Trial 3. Water and a calcium/phosphorus mineral with trace elements were provided free choice to all lambs during all trials. Lambs were individually penned and fed $1.5 \mathrm{~kg}$ of alfalfa pellets/day from 1000-1700 hours to meet maintenance requirements throughout all trials (NRC 1985).

Bitterweed was harvested from January through April in 1996 from the Texas Range Station in Barnhart, Tex., USA. Samples were air dried and equally mixed from each collection to assure consistency of hymenoxon levels in all samples. Mixed samples were ground through a 2 $\mathrm{mm}$ screen prior to dosing.

\section{Trial 1}

Thirty freshly weaned, castrated male Rambouillet and Rambouillet x Suffolk lambs weighing approximately $35 \mathrm{~kg}$, were randomly allocated to 1 of 4 treatments ( $\mathrm{n}=8 \mathrm{lambs} / \mathrm{treatment}$ except for Treatment 1 which consisted of 6 lambs). An unbalanced sample size was used because 2 lambs died just prior to initiation of the study. All lambs were offered dried, ground bitterweed (.264\% BW) in the morning (0800) for 45 min after fasting overnight. Calhoun et al. (1981) showed that $.264 \%$ BW of bitterweed readily caused toxicosis in another study. Treatments were dosed (by gavage) with varying levels of Darco KB ${ }^{\mathrm{TM}}$ activated charcoal (Norit Americas, Inc.). Treatments 1 through 4 received $0, .5,1$, or $1.5 \mathrm{~g} / \mathrm{kg} \mathrm{BW}$ of activated charcoal, respectively. Lambs were offered bitterweed and dosed with activated charcoal for 10 consecutive days.

Lambs typically reduce intake as hymenoxon levels increase (Calhoun et al. 1981), which suggests lambs receive aver- sive postingestive feedback and develop a conditioned food aversion (CFA) to bitterweed (Provenza et al. 1990, 1992, 1994). If activated charcoal reduces bitterweed toxicosis, presumably by adsorbing hymenoxon, then a CFA to bitterweed should not occur. Thus, increased intake of bitterweed (i.e., lack of CFA) is considered evidence of activated charcoal reducing toxicosis.

\section{Trial 2}

Because lambs did not eat bitterweed in Trial 1, a second trial was conducted using the learned aversion paradigm to determine if bitterweed would cause a conditioned food aversion to a novel food, and if activated charcoal would attenuate such aversions. The occurrence of an aversion to a novel food following dosing with bitterweed was considered evidence that bitterweed was causing toxicosis.

Lambs were fed $400 \mathrm{~g}$ of milo (Sorghum spp.) for 15 min daily followed by gavaging with bitterweed or bitterweed and activated charcoal. Intake of milo was measured on subsequent days to determine level of toxicosis.

Prior to dosing, lambs were fed milo on days 1 through 4 to familiarize lambs with milo. On day 5 through 15 , lambs were dosed with a mixture of activated charcoal (depending of treatment) and bitterweed. Bitterweed and activated charcoal were mixed with distilled water and delivered directly to the rumen by gavage.

\section{Trial 3}

Trial 3 was conducted to determine if animals would consume activated charcoal in a dietary supplement and to compare intake of bitterweed and 2 other forages when lambs were supplemented with a crude protein supplement with or without activated charcoal. Sixteen lambs were

Table 1. Ingredients and nutrient content of the $20 \%$ crude protein supplement used in Trial 2. Supplement was ground to facilitate mixing with activated charcoal.

\begin{tabular}{lc}
\hline \hline Ingredient & Ration \\
\hline & $(\%)$ \\
Milo sorghum grain & 37.6 \\
Cottonseed meal & 34.8 \\
Dehydrated alfalfa & 2.5 \\
Peanut hulls & 5.0 \\
Wheat middens & 7.5 \\
Calcium/phosphorus/salt/trace mineral & 12.5 \\
Nutrient Content & \\
Crude Protein & 20.0 \\
Crude Fat & 2.8 \\
Crude Fiber & 8.5 \\
TDN & 60.0 \\
\hline
\end{tabular}

randomly allocated to 2 treatments and placed in individual pens. Treatment 1 received $1 \mathrm{~g} / \mathrm{kg} \mathrm{BW}$ of activated charcoal mixed with a $20 \% \mathrm{CP}$ supplement (i.e., range cubes; Table 1). Range cubes were ground to facilitate mixing with activated charcoal. Treatment 2 received the ground $20 \%$ range cube without activated charcoal. Lambs were fed $400 \mathrm{~g}$ of supplement each day for $45 \mathrm{~min}$ and then exposed to 10 potted plants each of bitterweed, Texas wintergrass (Stipa leucotricha Trin.\& Rupr.), and engelmanndaisy (Engelmannia pinnatifida Nutt.). Both engelmanndaisy and Texas wintergrass are common cool season forages in west Texas. Thirty plants (10 each) were available during each exposure. All potted plants were kept in a vegetative state throughout the study.

Lambs were exposed to the potted plants for $10 \mathrm{~min}$ each day for 7 days. The number of bites of each species was recorded. Lambs were exposed in pairs of 2 lambs from the same treatment. When animals depleted forage, fresh plants were placed in the pasture. For the remainder of each day (1000-1700 hrs), lambs were returned to individual pens and fed alfalfa pellets $(1.5 \mathrm{~kg} /$ day $)$, water, and a calcium/phosphorus mineral with trace elements to meet maintenance requirements.

\section{Statistical Analysis}

Data were analyzed using repeated measures analysis of variance with day as the repeat measure; lambs (replications) were nested within treatments (Hicks 1993). Differences among means were assessed by least significant difference when $\mathrm{P}<$ 0.05 (Gomez and Gomez 1984). Data were analyzed with the statistical package JMP (SAS 1994). 
Table 2. Average intake of milo for all days when lambs were dosed with bitterweed or bitterweed and activated charcoal during Trial 2.

\begin{tabular}{lcc}
\hline \hline Activated Charcoal & Milo Intake & $\begin{array}{c}\text { Standard Error } \\
(\text { SEM })\end{array}$ \\
\hline$(\mathrm{g} / \mathrm{kg} \mathrm{BW})$ & $(\mathrm{g}) \mathrm{C}$ \\
0.0 & $216^{\mathrm{C}}$ & 17.1 \\
0.5 & $252^{\mathrm{BC}}$ & 17.1 \\
1.0 & $296^{\mathrm{AB}}$ & 17.1 \\
1.5 & $303^{\mathrm{A}}$ & 19.7 \\
$\mathrm{Acc}_{\text {Means within columns with different superscripts differ }(\mathrm{P}<0.05) .}$ \\
$\operatorname{LSD}_{(0.05)}=49.7$.
\end{tabular}

\section{Results}

\section{Trial 1}

When offered dried ground bitterweed after fasting overnight, lambs did not consume measurable amounts. We mixed bitterweed with corn to improve acceptance, but lambs still refused to eat bitterweed even after several days of exposure. Animals must consume sufficient amounts of a food to pair the flavor of the food with its postingestive consequences (du Toit et al. 1991). No lambs were dosed because of the lack of bitterweed intake. Because lambs refused to bitterweed even after the basal ration was reduced below maintenance requirements, Trial 1 was stopped after 10 days.

\section{Trial 2}

After 4 days of eating milo, lambs were eating $340 \mathrm{~g}$ on average within $15 \mathrm{~min}$. On day 5 through 15, lambs were dosed with $.264 \% \mathrm{BW}$ of bitterweed and either $0, .5$, 1 , or $1.5 \mathrm{~g} / \mathrm{kg} \mathrm{BW}$ of activated charcoal according to treatment. and activated charcoal, dose of activated charcoal affected intake of milo (Table 2). Lambs consumed more $(\mathrm{P}<0.05)$ milo if they received $1.5 \mathrm{~g} / \mathrm{kg} \mathrm{BW}$ as opposed to 0 or $.5 \mathrm{~g} / \mathrm{kg} \mathrm{BW}$ of activated charcoal. Lambs that received $1 \mathrm{~g} / \mathrm{kg} \mathrm{BW}$ consumed more milo than those that received $0 \mathrm{~g} / \mathrm{kg}$ of activated charcoal, while those that received 0 and $0.5 \mathrm{~g} / \mathrm{kg}$ BW consumed similar $(\mathrm{P}>0.05)$ amounts of milo. As the study continued, intake of milo decreased for all treatments but differences among
When lambs were dosed with bitterweed

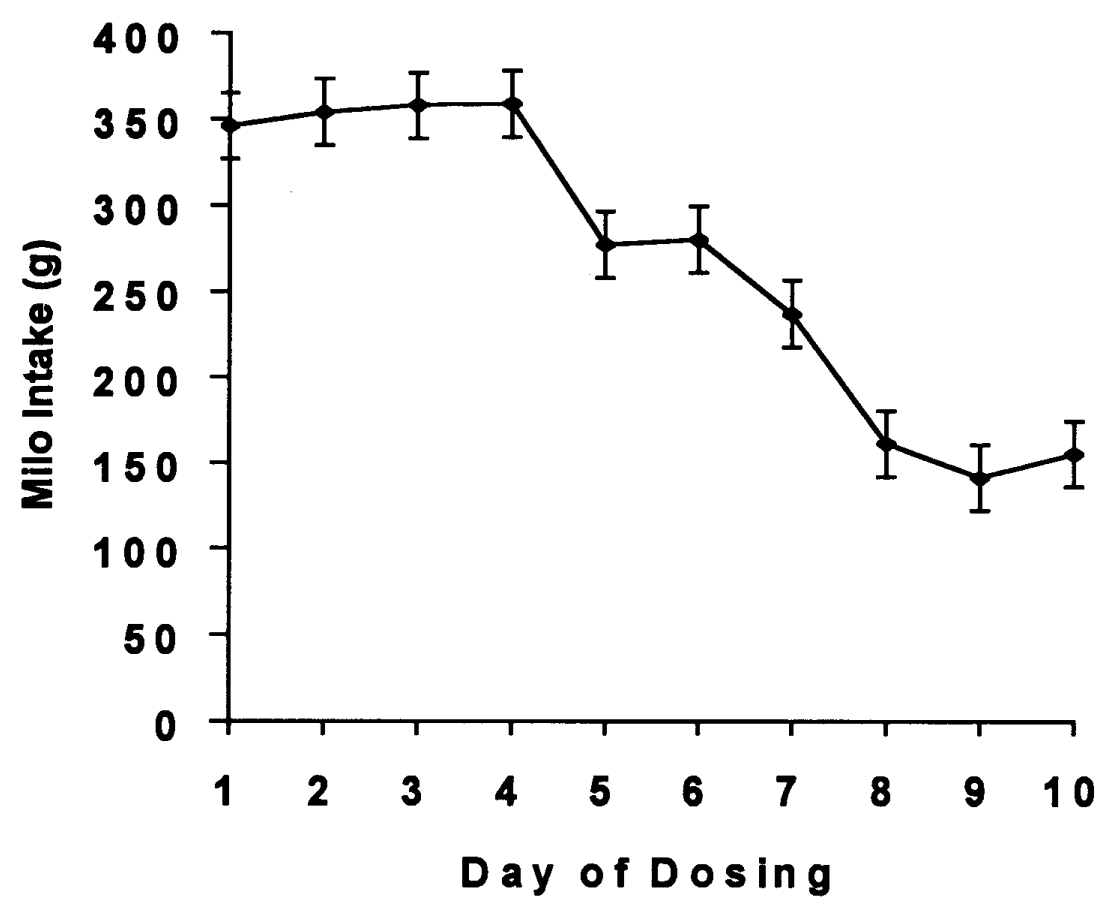

Fig. 1. Average intake of milo following 4 days of familiarization with this food during Trial 2. Throughout the 10 days of exposure, lambs were dosed with either bitterweed alone or bitterweed and activated charcoal at varying levels $(0,0.5,1.0$, or $1.5 \mathrm{~g} / \mathrm{kg} \mathrm{BW})$. The treatment $X$ day interaction was not significant $(\mathbf{P}>0.05)$

treatments persisted and the treatment by day interaction was not significant (Fig. 1).

It was important that lambs consume enough milo on a given day to associate the flavor of milo with any postingestive feedback from bitterweed or activated charcoal and bitterweed. An individual was not dosed if it did not consume at least $200 \mathrm{~g}$ of milo on a given day. Intake of milo fluctuated daily especially for lambs receiving 0 or $.5 \mathrm{~g} / \mathrm{kg} \mathrm{BW}$ of activated charcoal. Thus, not all lambs were dosed every day.

When we examined lambs' intake only on the days after they were dosed with bitterweed or bitterweed and activated charcoal, lambs dosed with bitterweed alone ate less $(\mathrm{P}<0.05)$ milo than lambs that received activated charcoal and bitterweed (Table 3). Milo intake was not affected $(\mathrm{P}>0.05)$ by dose of activated charcoal on the day directly after dosing.

\section{Trial 3}

Lambs readily consumed the $20 \% \mathrm{CP}$ supplement with (302 g/day) and without (297 g/day) activated charcoal ( $>>0.05)$. Lambs that received activated charcoal took more $(\mathrm{P}<0.05)$ bites of bitterweed and engelmanndaisy than lambs that received the $20 \% \mathrm{CP}$ supplement alone (Table 4). All lambs consumed similar amounts of Texas wintergrass.

\section{Discussion}

\section{Trial 1}

In Trial 1, lambs refused to eat bitterweed after several days of exposure even after their basal diet of alfalfa pellets was reduced to half maintenance and bitterweed was mixed with corn. Lambs may have consumed enough during the initial feeding of bitterweed to receive immediate aversive feedback causing avoidance of bitterweed on subsequent days. Some toxins cause rapid aversive postingestive feedback shortly after initiation of intake by ruminants (Provenza 1995, 1996). Similarly, some insects decrease intake in response to toxins within $30 \mathrm{sec}$ through postingestive feedback (Glendinning 1996). Bitterweed can cause death at low levels $\left(\mathrm{LD}_{50}=0.5\right.$ to $\left.1.3 \% \mathrm{BW}\right)$ (Calhoun et al. 1981, Ueckert and Calhoun 1988). Thus, any evolved mechanism of recognizing toxin levels in bitterweed would rely on immediate postingestive feedback when small amounts are consumed.

Sheep typically consume bitterweed when it is actively growing during late winter and early spring (Pfeiffer and 
Table 3. Average intake of milo for days directly after dosing with bitterweed or bitterweed and activated charcoal dosing during Trial 2. On days when lambs did not consume $\geq 200 \mathrm{~g}$ of milo, they were not dosed and excluded from the analysis.

\begin{tabular}{lcc}
\hline \hline Activated Charcoal & Milo Intake & $\begin{array}{c}\text { Standard Error } \\
(\text { SEM })\end{array}$ \\
\hline$(\mathrm{g} / \mathrm{kg} \mathrm{BW})$ & $(\mathrm{g})$ & \\
0.0 & $196^{\mathrm{B}}$ & 30.3 \\
0.5 & $263^{\mathrm{A}}$ & 26.2 \\
1.0 & $287^{\mathrm{A}}$ & 19.5 \\
1.5 & $303^{\mathrm{A}}$ & 19.2 \\
\hline $\mathrm{A}-\mathrm{B}$ &
\end{tabular}

${ }^{\mathrm{A}-\mathrm{B}}$ Means within columns with different superscripts differ $(\mathrm{P}<0.05)$.

$\operatorname{LSD}(0.05)=52.97$

Calhoun 1987). We fed dry, ground bitterweed during the summer and drying and grinding may have depressed intake. However, lambs also refuse to consume bitterweed when other forages are available in field studies during winter (Ueckert and Calhoun 1988). Bitterweed has a very stringent taste which may initially limit intake. Bitter flavors are often associated with toxins (Provenza et al. 1992), and animals may innately avoid bitter flavors to avoid toxicosis (Bartoshuk 1991). However, taste alone cannot explain acceptance or avoidance of foods (Launchbaugh et al. 1993). Animals can be conditioned to prefer bitter-flavored foods if they are paired with nutrients (Mehiel 1991, Sclafani 1991). Because bitterweed grows when most forages are dormant, it may be the only readily digestible and nutritious forage available. Similar situations exist for other poisonous plants; cattle often consume locoweed (Astragalas sp., Oxytropis sp.) until it reaches maturity and other forages become available (Ralphs et al. 1993).

\section{Trial 2}

Lambs dosed with bitterweed alone consumed considerably less than lambs that received bitterweed with activated charcoal, which suggests activated charcoal alleviated some of the toxic effects of bitterweed. Activated charcoal's positivelycharged molecular surface binds with the

Table 4. The number of bites of bitterweed, Texas wintergrass, and engelmanndaisy by individual lambs exposed to a simulated pasture for $10 \mathrm{~min} / \mathrm{day}$ over 7 days during Trial 3. Lambs were exposed as pairs that either received activated charcoal plus a $20 \% \mathrm{CP}$ supplement or a $20 \% \mathrm{CP}$ supplement alone.

\begin{tabular}{lccc}
\hline \hline $\begin{array}{l}\text { Activated Charcoal } \\
\text { Supplement }\end{array}$ & Bitterweed & Texas Wintergrass & Engelmanndaisy \\
\hline & $-\cdots-\cdots$ & Number of Bites/10 min - - - - - - \\
Yes & $12.9^{\mathrm{A}}$ & 15.2 & $6.6^{\mathrm{A}}$ \\
No & $2.3^{\mathrm{B}}$ & 12.2 & $1.0^{\mathrm{B}}$ \\
\hline
\end{tabular}

Means within columns with different superscripts differ $(\mathrm{P}<0.05)$.

negatively-charged molecular surface of most toxins, resulting in covalent bonding. Thus, most toxins should be adsorbed before digested (Edwards and McCredie 1967). Human deaths by poisoning are prevented when activated charcoal adsorbs toxins already ingested but not digested (Decker et al. 1968, Hayden and Comstock 1975, Levy 1982). Given the design of this study, we were unable to determine if activated charcoal adsorbed hymenoxon prior to digestion. Nevertheless, it seems likely that adsorption occurred given that lambs receiving the higher doses of activated charcoal (1 and $1.5 \mathrm{~g} / \mathrm{kg} \mathrm{BW}$ ) consumed more bitterweed. It may be that activated charcoal resulted in higher intake for other reasons. For instance, dosing with activated charcoal may have altered the rumen environment or other digestive functions which affected toxin availability.

Consumption of milo decreased across all treatments over time. Lambs may have experienced some degree of compaction and reduced ingesta flow from the excessive amounts of activated charcoal. Sodium or magnesium sulfate should be used in conjunction with activated charcoal to prevent compaction of the intestinal tract (Buck and Bratich 1986). We did not use a laxative which may explain the decline.

Alternatively, activated charcoal may have failed to prevent continued toxicosis that developed after several days of dosing with bitterweed. Low levels of bitterweed can cause chronic toxicosis when consumed over several days (Witzel et al. 1977, Ueckert and Calhoun 1988). Chronic or subacute bitterweed toxicosis causes relatively obvious, overt symptoms (e.g., disorientation, blindness, listlessness), but we did not observe overt signs of toxicosis during the study. However, in another study, 1 lamb died from chronic bitterweed toxicosis without exhibiting any of the typical overt symptoms (Bisson and Scott unpubl. data).

\section{Trial 3}

Trial 3 was conducted to determine if sheep would eat activated charcoal in a supplement and to monitor subsequent intake of bitterweed and 2 other common forage plants. Lambs readily ate the $20 \%$ crude protein range cube with and without activated charcoal. Lambs supplemented with activated charcoal consumed more bitterweed and engelmanndaisy, suggesting activated charcoal fed with a supplement may prevent bitterweed toxicosis. Engelmanndaisy is considered one of the most palatable forbs in west central Texas, but lambs that not did receive activated charcoal avoided engelmanndaisy. Engelmanndaisy may contain low levels of secondary metabolites that limit intake.

Sheep in Trial 3 took $15-35$ bites in 10 min of exposure to potted plants. Other studies have reported sheep taking 50-65 bites in 2-3 min (Burritt and Provenza 1990, Ralphs et al. 1991). Lambs probably took fewer bites of the potted plants because they were satiated; they received $400 \mathrm{~g}$ of supplement immediately before exposure to the potted plants.

\section{General Discussion}

Other efforts to feed lambs a compound to prevent toxicosis have been unsuccessful because of unpalatability (Ueckert and Calhoun 1988). L-cysteine prevents toxicosis (Rowe et al. 1980), but lambs avoid supplements containing high levels of Lcysteine (Calhoun et al. 1986). The antioxidant Santoquin (6-ethoxy-1,2, dihydro2,2,4-trimethylquinoline) also prevents toxicosis (Kim et al. 1982, Calhoun et al. 1989), but Santoquin reduces palatability when added to supplements at $0.5 \%$ (Calhoun et al. 1986, Ueckert and Calhoun 1988). Activated charcoal may be an effective replacement for other supplement additives because (1) lambs will readily consume sufficient amounts of activated charcoal, and (2) activated charcoal appears to attenuate bitterweed toxicity.

Dollahite et al. (1973) showed similar success in preventing bitterweed toxicosis by dosing lambs with $.5 \% \mathrm{BW}$ of activated charcoal, but they were unable to prevent toxicosis by feeding activated charcoal in a supplement. Their source and type of charcoal was not clear. We used a type of charcoal with a large surface area due to a very small particle size to bind with toxins; differences in charcoal may explain discrepancies between the 2 studies. Dollahite et al. (1973) also fed activated charcoal supplement as a pelleted feed. Pelleting requires extreme heat and pressure to form pellets which may reduce the adsorbative capacity of activated charcoal. 
Activated charcoal may be effective in binding other phytotoxins. Buck and Bratich (1986) suggested activated charcoal should be effective in treating toxicosis induced by mycotoxins, plant alkaloids, glycosides, and most other phytotoxins. Activated charcoal effectively adsorbed phenolics from Terminalia catappa and Mangifera indica on the African Island of Zanzibar (Struhsaker et al. 1997). Activated charcoal also reduces toxicity from aflatoxins in chickens (Decker and Corby 1980, Ademoyero and Dalvi 1983, Dalvi and Ademoyero 1984, Dalvi and McGowan 1984) However, other efforts to use activated charcoal to treat phytotoxicosis have produced unfavorable results; activated charcoal has only resulted in limited success in binding terpenes in sagebrush (Artemisisa sp.) in northern Utah (Provenza, pers. comm.). Further investigations are needed to quantify the scope of activated charcoal to treat(prevent) plant-induced toxicosis.

\section{Implications}

Veterinarians commonly treat a wide variety of toxicosis cases with activated charcoal (Buck and Bratich 1986), yet the use of activated charcoal by livestock producers is rare. Producers typically pen animals suffering from bitterweed toxicosis and feed them a high-protein diet. Drenching with activated charcoal $(1 \mathrm{~g} / \mathrm{kg}$ BW) immediately after observing toxicosis is likely to increase survival if hymenoxon is still in the digestive tract and adsorption occurs. Nevertheless, for activated charcoal to become widely used against bitterweed toxicosis, it should be offered in the form of a supplement. However, there are no data on appropriate supplementing frequencies. Similarly, there are several grades of activated charcoal that may vary in ability to adsorb hymenoxon; commercial varieties of activated charcoal typically differ in ability to adsorb toxins (Cooney and Struhsaker 1997). Finally, the physiological effect of activated charcoal remains unclear. Future studies should investigate activated charcoal's affect on digestive function and animal health.

\section{Literature Cited}

Ademoyero, A.A. and R.R. Dalvi. 1983. Efficacy of activated charcoal and other agents in the reduction of hepatotoxic effects of a single dose of aflatoxin B1 in chickens Aspergillus flavus, Aspergillus parasiticus. Toxicol. Letters. 16:153-157.
Bartoshuk, L.M. 1991. Taste, smell, and pleasure. pp. 15-25 In: R.C. Bolles (Editor), The Hedonics of Taste. Lawrence Erlbaum Assoc., New Jersey.

Buck, W.B. and P.M. Bratich. 1986. Activated charcoal: Preventing unnecessary death by poisoning. Vet. Med. January:73-77.

Burritt, E.A. and F.D. Provenza. 1990. Food aversion learning in sheep: persistence of conditioned taste aversions to palatable shrubs (Cercocarpus montanus and Amelanchier alnifolia). J. Anim. Sci. 68:1003-1007.

Calhoun, M.C., B.C. Baldwin, Jr., S.W. Kuhlmann, and H.L. Kim. 1986. Bitterweed antidote research. Tex. Agr. Exp. Stat. Prog. Rep. 4382.

Calhoun, M.C., B.C. Baldwin, Jr., S.W. Kuhlmann, and H.L. Kim. 1988. Experimental prevention of bitterweed (Hymenoxys odorata) poisoning of sheep. Amer. J. Vet. Res. 50:1642-1646.

Calhoun. M.C., D.N. Ueckert, C.W. Livingston, Jr., and B.C. Baldwin. 1981. Effects of bitterweed (Hymenoxys odorata) on voluntary feed intake and serum constituents of sheep. Amer. J. Vet. Res. 42:1713-1717.

Conner, J.R., J.L. Schuster, and E.M. Bailey, Jr. 1988. Impact of bitterweed on the economics of sheep production in the Texas Edwards Plateau. pp.145-151 In: James, L.F., M.H. Ralphs, and D.B. Nielsen (Eds.), The Ecology and Economic Impact of Poisonous Plants on Livestock Production. Westview Press, Boulder, Colo.

Cooney, D.O. and T.T. Struhasaker. 1997. Adsorptive capacity of charcoals eaten by Zanzibar columbus monkeys: implications for reducing dietary toxins. Internat. J. Primatol. 18:235-246.

Dalvi, R.R. and A.A. Ademoyero. 1984. Toxic effects of aflatoxin B1 in chickens given feed contaminated with Aspergillus flavus and reduction of the toxicity by activated charcoal and some chemical agents. Avian Diseases. 28:6169.

Dalvi, R.R. and C. McGowan. 1984. Experimental induction of chronic aflatoxicosis in chickens by purified aflatoxin B 1 and its reversal by activated charcoal, phenobarbital, and reduced glutathione. Poultry Sci. 63:485-491.

Decker, W.J. and D.G. Corby. 1980. Activated charcoal adsorbs aflatoxin B1 feed, decontamination. Veterinary and human toxicology. 22:388-389.

Decker, W.J., H.F. Combs, and D.G. Corby. 1968. Adsorption of drugs and poisons by activated charcoal. Toxicol. Appl. Pharmacol. 13:454-460.

Dollahite, J.W., L.D. Rowe, H.L. Kim, and B.J. Camp. 1973. Control of bitterweed (Hymenoxys odorata) poisoning in sheep. Tex. Agr. Exp. Stat. Rep. 3149.

du Toit, J.T., Provenza, F.D. and Nastis, A. 1991. Conditioned taste aversions: how sick must a ruminant get before it learns about toxicity in foods? Appl. Anim. Behav. Sci. 30:35-46.
Edwards, K.D.G., and M. McCredie. 1967. Studies on the binding properties of acidic, basic and neutral drugs to anion and cation exchange resins and charcoal in vitro. Med. J. Aust. March 18:534-539.

Glendinning, J.I. 1996. Is chemosensory input essential for the rapid rejection of toxic foods? J. Exp. Biol. 199:1523-1534.

Gomez, K.A. and A.A. Gomez. 1984. Statistical Procedures for Agricultural Research. pp. 187-207. John Wiley and Sons, New York.

Hayden, J.W. and E.G. Comstock. 1975. Use of activated charcoal in acute poisoning. Clin. Toxicol. 8:515-533.

Hicks, C.R. 1993. Fundamental Concepts in the Design of Experiments. pp. 173-199. Saunders College Publishing, New York.

Ivie, G.W., K.A. Witzel, W. Herz, R. Kannan, J.O. Norman, D.D. Rushing, J.H. Johnson, L.D. Rowe, and J.A. Veech. 1975. Hymenovin. Major toxic constituent of bitterweed (Hymenoxys odorata DC.). J. Agr. Food Chem. 23:841-845.

Kim, H.L., L.D. Rowe, and B.J. Camp. 1975. Hymenoxon, a poisonous sesquiterpene lactone from Hymenoxys odorata DC. (Compositeae). Sothwest. Vet. 27:84-86.

Kim, H.L., A.C. Anderson, B.W. Herring, L.P. Jones, and M.C. Calhoun. 1982. Protective effects of antioxidants on bitterweed (Hymenoxys odorata DC) toxicity in sheep. Amer. J. Vet. Res. 43:1945-1950.

Launchbaugh, K.L., F.D. Provenza, and E.A. Burritt. 1993. How herbivores track variable environments: response to variability of phytotoxins. J. Chem. Ecol. 19:1047-1056

Levy, G. 1982. Gastrointestinal clearance of drugs with activated charcoal. N. Engl. J. Med. 307:676-678.

Mehiel, R. 1991. Hedonic-shift conditioning with calories. pp. 107-126. In: R.C. Bolles (Editor), The Hedonics of Taste. Lawrence Erlbaum Assoc., New Jersey.

NRC. 1985. Nutrient Requirements of Sheep (6th Ed.). National Academy Press Washington, D.C.

Pettersen, R.C. and H.L. Kim. 1976. X-ray structures of hymenoxon and hymenolane: pseudoquaianolides isolated from Hymenoxys odorata DC. (bitterweed). J. Chem. Soc. Perkin Transactions II:1399-1403.

Pfeiffer, F.A., and M.C. Calhoun. 1987. Effects of environmental, site and phenological factors on hymenoxon content of bitterweed (Hymenoxys odorata). J. Anim. Sci. 65:1553-1562

Provenza, F.D. 1995. Postingestive feedback as an elementary determinant of food preferences and intake in ruminants. J. Range Manage. 48:2-17

Provenza, F.D. 1996. Acquired aversions as the basis for varied diets of ruminants foraging on rangelands. J. Anim. Sci. 74:2010-2020.

Provenza, F.D., J.L. Lynch, and J.V. Nolan. 1994. Food aversion conditioned in anesthetized sheep. Physiol. Behav. 55:429-432. 
Provenza, F.D., J.A. Pfister, and C.D. Cheney. 1992. Mechanisms of learning in diet selection with reference to phytotoxicosis in herbivores. J. Range Manage. 45:3645.

Provenza, F.D., E.A. Burritt, T.P. Clausen, J.P. Bryant, P.B. Bryant, P.B. Reichardt, and R.A. Distel. 1990. Conditioned flavor aversion: a mechanism for goats to avoid condensed tannins in blackbrush. Am. Natur.136:810-828.

Ralphs, M.H., K.E. Panter, and L.F. James. 1991. Grazing behavior and forage preference of sheep with chronic locoweed toxicosis suggest no addiction. J. Range Manage. 44:208-209.
Ralphs, M.H., D. Graham, R.J. Molyneux, and L.F. James. 1993. Seasonal grazing of locoweeds by cattle in northern New Mexico. J. Range Manage. 46:416-420.

Rowe, L.D., H.L. Kim, and B.J. Camp. 1980. The antagonistic effect of L-cysteine in experimental hymenoxon intoxication in sheep. Amer. J. Vet. Res. 41:484-486.

SAS. 1994. JMP User's Guide, Version 3.1. SAS Institute Inc., North Carolina.

Sclafani, A. 1991. Conditioned food preferences. Bull. Psychon. Soc. 29:256-260.

Struhsaker, T.T., D.O. Cooney, and K.S. Siex. 1997. Charcoal consumption by Zanzibar red colobus monkeys: its function and its ecological and demographic consequences. Int. J. Primatol. 18:61-72.
Ueckert, D.N., and M.C. Calhoun. 1988. Ecology and toxicology of bitterweed (Hymenoxys odorata). pp. 131-143. In: James, L.F., M.H. Ralphs, and D.B. Nielsen (Eds.) The Ecology and Impact of Poisonous Plants on Livestock Production. Westview Press, Boulder, Colo.

Ueckert, D.N., C.J. Scifres, S.G. Whisenant, and J.L. Mutz. 1980. Control of bitterweed with herbicides. J. Range Manage. 33:465-469.

Witzel, D.A., L.P. Jones, and G.W. Ivie. 1977. Pathology of subacute bitterweed (Hymenoxys odorata) poisoning in sheep. Vet. Pathol. 14:73-78. 